\title{
二重式トレミー管を用いた土砂投入 \\ Dumping Dredged Material with Double-Tremie
}

\section{奥村研一*・手塚哲**・高木幸夫*** ・五明美智男 $* * * *$ ・飯田勲 $* * * * *$ ・矢内栄二******}

Kenichi Okumura, Tetu Tezuka, Yukio Takagi, Michio Gomyoh, Isao Iida, Eiji Yauchi

\begin{abstract}
Double-tremie work was applied to mitigate some effects caused by dumping dredged materials. Field investigations were carried out in order to clarify its efficiency, which can reduce the discharge of suspended solids by circulating water body in it. It is found that natural circulation did not occur under an intermittent dumping condition, but an additional compulsory circulation by aeration could keep suspended solids in the tremie at a higher level and reduce the discharge to the surrounding water.
\end{abstract}

Keywords: double-tremie, dredged material, suspended solids, aeration

\section{1.はじめに}

川崎港東扇島地区の前面海域では、昭和 49 年から 53 年にかけ東扇島の埋立用材として海底から土砂が採取さ れ、現在でも広い範囲に窪地が残存している。そのため、小中型のタンカー等の錨泊地として利用されてはいる ものの、海底地盤に見られる不陸のため船舶投錨地として良好とは言い難いのが現況である。また、窪地海底付 近では、海水の滞留により貧酸素水塊が発生しやすく、海洋生物の生息環境としても好ましくない。こうした現 状をふまえ、現在この地区で進められている コンテナ岸壁等の泊地整備事業においては、 航路泊地の浚渫により発生する土砂を整備用 材として活用し、錨泊地機能の向上と滞留域 解消による水質改善を図ることとした。

工事の実施にあたっては、土砂投入による 濁りの拡散を出来るだけ抑えることはもちろ んのこと、錨泊地としての利用上広範囲な污 濁防止膜の敷設を避ける必要があった。そこ で、環境への影響をできるだけ少なくし、し かも狭い作業占有域から計画地点に確実に土 砂を投入する方法として、二重式トレミー管 を用いた工法を採用することとした。本論文 では、二重式トレミー管近傍での現地観測結 果について報告するとともに、二重式トレミ 一管の污濁低減機構について考察する。

\section{2. 二重式トレミー管の特徵}

今回用いた二重式トレミー管は、図-1に 示すような構造であり、土砂投入時に発生す る内管内と外管内の水位差による循環流を利 用し、浮遊しやすい土粒子を管内に滞留させ 污濁発生を低減しようとするものである。(こ

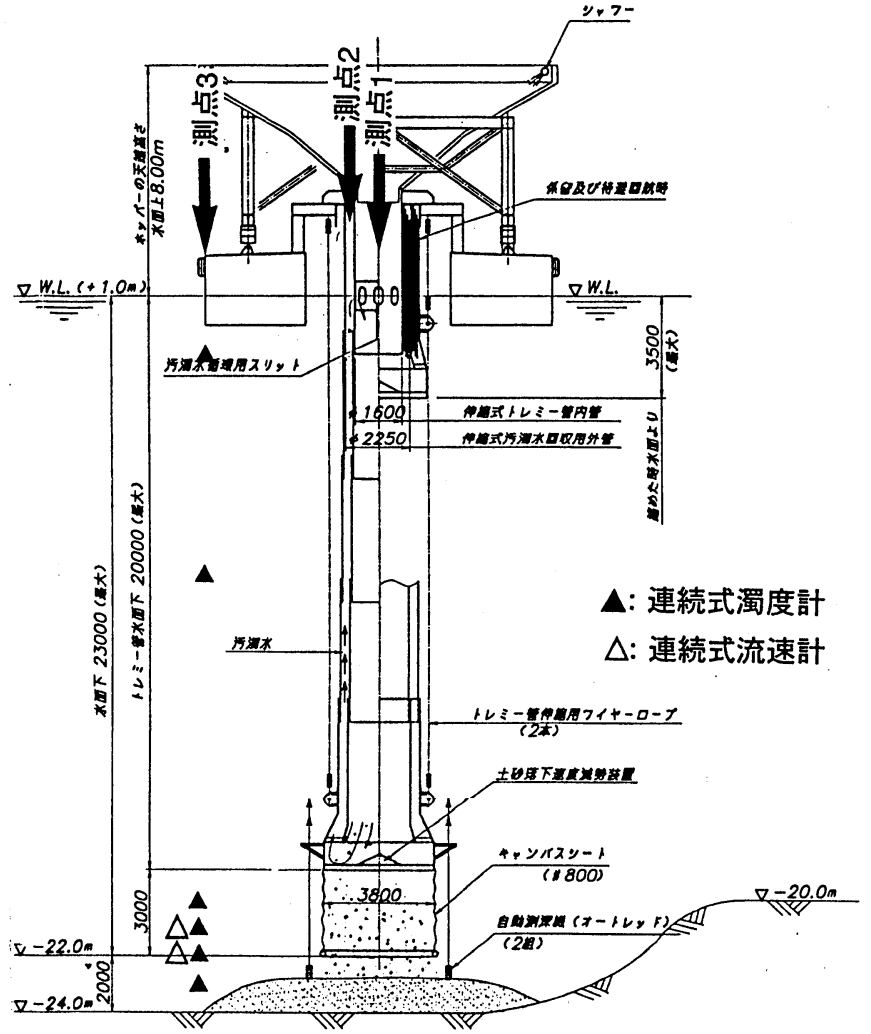

図-1 二重式トレミー管の構造と調査位置

* 正会員 前 運輸省第二港湾建設局京浜港湾工事事務所（广 221 横浜市神奈川区山内町 1 丁目 2 番）

(現 本州四国連絡橋公団)

$\begin{aligned} * * & \text { 運輸省第二港湾建設局京浜港湾工事事務所 } \\ * * * & \text { 前 運輸省第二港湾建設局京浜港湾工事事務所（現 運輸省第二港湾建設局東京空港工事事務所） } \\ * * * * & \text { 正会員 } \text { 東亜建設工業（株）技術研究所 } \\ * * * * * & \text { 正会員 東亜建設工業（株）横浜支店土木部 } \\ * * * * * * & \text { 正会員 東亜建設工業 (株) 土木本部設計部 }\end{aligned}$


表-1＼cjkstart各測点における調査内容

\begin{tabular}{|c|c|c|c|c|}
\hline \multicolumn{2}{|r|}{ 測点 $(\mathrm{m})$} & 目的 & 調査項目・方法 & 調査サイクル \\
\hline 1 & $x=0$ & 污濁循環効果の確認 & 投入式濁度計により $1 \mathrm{~m}$ 毎に測定 & 1 隻あたりの土砂投入終了後 \\
\hline 2 & \multirow[t]{2}{*}{$x=1.2-1.4$} & \multirow[t]{2}{*}{ 污濁循環効果の確認 } & (1)海面から $5 \mathrm{~m}$ ごとに採水し $\mathrm{SS}$ を測定 & 1 隻あたりの土砂投入終了後 \\
\hline 2 & & & (2)電磁流速計により海面下 $13 \mathrm{~m}$ で測定 & 土砂投入中 \\
\hline \multirow[t]{2}{*}{3} & \multirow[t]{2}{*}{$x=6$} & 污濁拡散状況 & $\begin{array}{l}\text { 表層(-2m)、中層(-10m)、下層(海底から } \\
+1,2,3,4 \mathrm{~m}) \text { で連続式濁度計で測定 } \\
\end{array}$ & 施工直前から終日 \\
\hline & & 土砂投入時流況 & $\begin{array}{l}\text { 下層(海底かり }+1,2 \mathrm{~m}) \text { で、連続式流速計 } \\
\text { により測定 }\end{array}$ & 施工直前から終日 \\
\hline 14 & $x=23$ & 污濁拡散状況 & 投入式濁度計により $0.5 \mathrm{~m}$ 毎に測定 & 土砂投入中 10 分毎 \\
\hline
\end{tabular}

こでは、外側、内側の管をそれぞれ外管、内管と呼び、外管と内管の間を外管内、内管内側の土砂が落下する部 分を内管内と定義する)。内管内と外管内の水の交換は、トレミー下端の開口部および内管静水面付近のスリッ ト部で生じる。また、バケットによる断続的な投入時においても循環流が促進されるように、内管下端に設置し た 8 個の空気穴より外管内に向け空気を発生できるようにしている。

\section{3. 工事および調查概要}

3-1. 工事状況

今回の施工区域内には水深 24 ～ $26 \mathrm{~m}$ の窪地が散在している。工事は、その一部に約 17 万 9 千 $\mathrm{m}^{3}$ の土砂を投

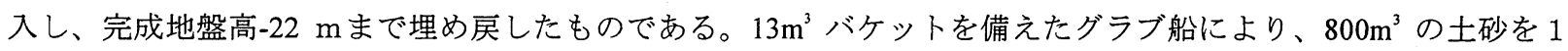
時間前後で投入することが出来、バケット 1 回あたりの投入サイクルタイムは約 1 分であった。

\section{$3-2$. 調查内容}

通常、工事による污濁については、污濁 発生原単位を調査する場合が多い（たとえ ば佐藤、1987)。しかしながら、本調査では、 錨泊地内での係留および定点観測が困難で あることから、トレミーを艤装した台船上 で調查可能な位置と方法を選定した。

二重管トレミー近傍に 4 つの測点を設け、それぞれ(1)測点 $1:$ 内管内中心部 $(x=0 \mathrm{~m})$ 、(2)測点 $2:$ 外管内 $(x=1.2$ $\sim 1.4 \mathrm{~m}$ )、(3)測点 $3:$ 外管近傍 $(x=6 \mathrm{~m})$ 、(4)測点 $4:$ 周辺 ( $x=23 \mathrm{~m})$ とした (図-1 参照)。各測点における調査 目的・項目・方法・調査サイクルは、表-1に示すとおりである。特に、污濁の指標としては濁度および SSを測 定した。また、投入土砂の性状把握を目的として、比重、粒度を測定するとともに、濁度と SS の相関について 室内実験を行った。

各調査は表- 2 に示すような日程と投入条件で実施した。エアレーション時の空気放出流量は $0.5 \sim 1.0 \mathrm{~m}^{3} / \mathrm{min}$ である。

\section{4. 調査結果}

\section{4-1. 投入土砂特性}

（1）投入土砂の性状

土砂供給元である浚渫地点の平面的位置あるいは深度 の違いにより、施工全期間を通して投入土砂性状に若干 の違いが見られた。しかしながら、現地観測期間中の土 砂性状はほぼ一定しており、土粒子比重 2.67、シルト分

- 粘土分含有率 $94 \%$ 、自然含水比 $70 \%$ となっている。

（2）投入土砂の濁度・SS 特性

光学的測定法により得られる濁度は土砂の色、粒径な

どに依存し、海域底泥では SS と大きく異なる場合がある。今回用いた土砂では、投入式・連続式濁度計の濁度 T と SS の関係として、図-2に示すような関係が得られている。これより、現場海水（土砂混入無し）の SS 濃度 をぜロとし、次の 2 式により濁度を SSに換算し解析に用いることとした。

$$
\mathrm{SS}=0.003 \mathrm{~T}^{2}+0.018 \mathrm{~T}+98.588 \quad(\mathrm{~T} \geqq 400 \mathrm{ppm}) 、 \mathrm{SS}=1.458 \mathrm{~T}-11.957 \quad(\mathrm{~T} \leqq 400 \mathrm{ppm})
$$


4-2. トレミ一近傍での SS の移流拡 散現象

投入された土砂は、トレミー内管 内を落下した後、一部は直下の海底 に堆積し残りは周囲へと拡がる。砂 の場合には、海水の抵抗、底面摩擦 の影響を受け速度を減じつつ、前進 しながら砂粒子を沈殿させていく （小川、竹内、1969）。一方、シル 卜質の土砂の場合には、密度流的な 挙動を示し、砂粒子に比べ污濁の拡 がる範囲も大きくなる。

本調査では、投入後の水平流が卓 越すると考えられる $\mathrm{x}=6 \mathrm{~m}$ 地点と 台船上で最も距離の取れる $\mathrm{x}=23 \mathrm{~m}$ 地点で、SS の移流拡散現象につい て検討した。
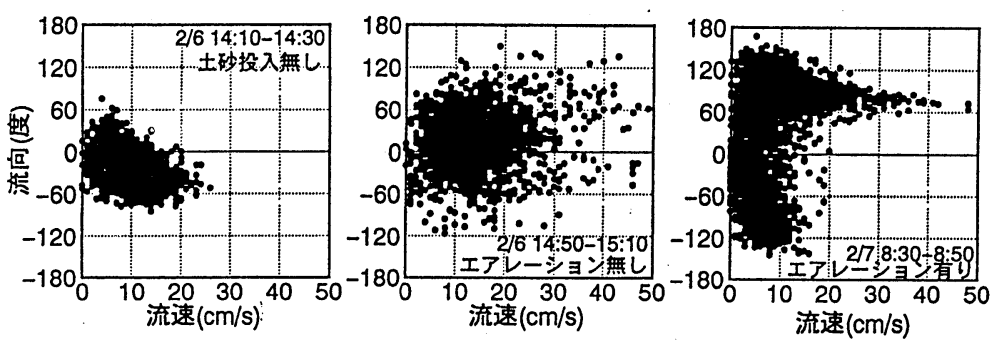

(a) 海底上 $+2 \mathrm{~m}$
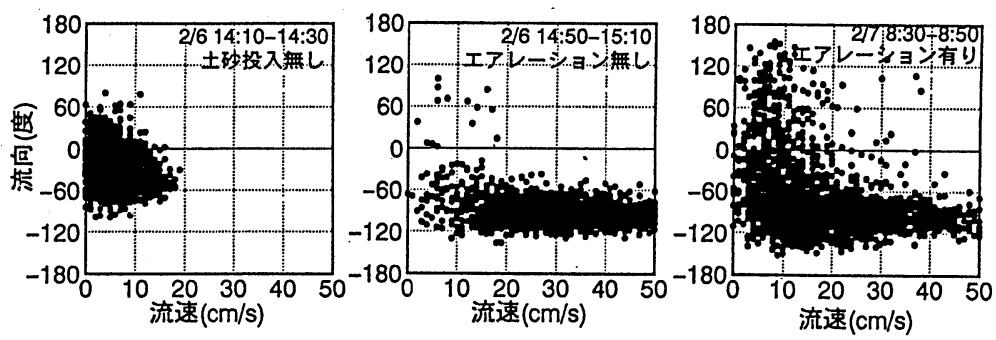

(b) 海底上 $+1 \mathrm{~m}$
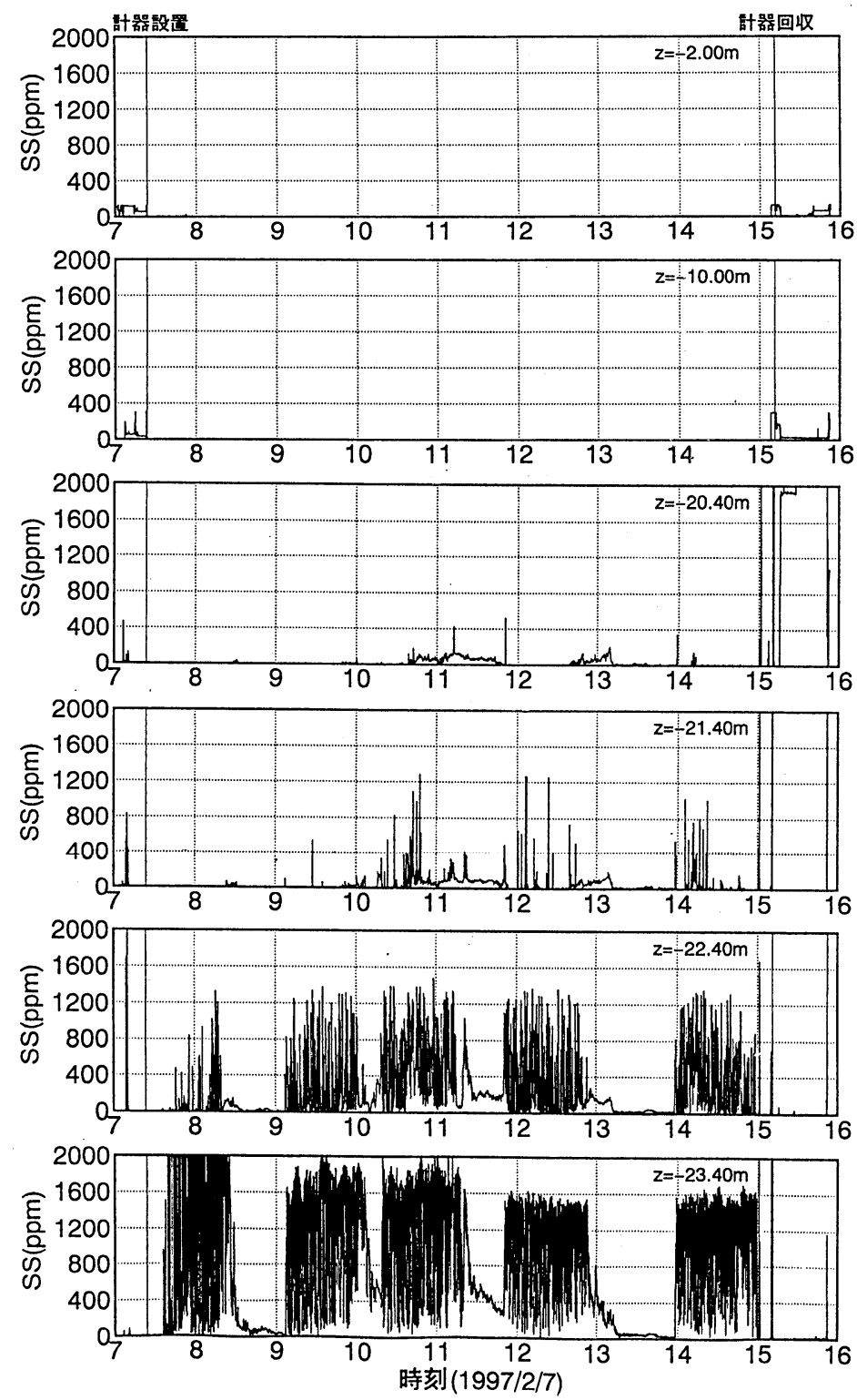

図-4 $\mathrm{x}=6 \mathrm{~m}$ における表層、中層、底層の SSS の変化

\section{（1）二重式トレミー管近傍における底層 流速変動}

図-3 は、 $x=6 \mathrm{~m}$ における海底上 $+2 \mathrm{~m} 、+1$ $\mathrm{m}$ での土砂投入前後の流向、流速変動の 一例を示したものである。ここで、 $\mathrm{x}=6$ $\mathrm{m}$ における流向は、 $-90 \sim-100$ 度が $\mathrm{x}$ の

$(+)$ 方向（トレミー中心 $\rightarrow$ 周辺） 、 80 〜 90 度が $\mathrm{x}$ の (-) 方向（周辺 $\rightarrow$ トミ 一中心）を示している。

土砂投入前後で底層の流況は大きく変 化し、海底上+1 mでは投入後トレミー中 心から周囲へ拡がる流れが卓越するよう になり、その大きさも投入前の場の流速 の数倍に達している。この傾向は、エア レーションの有無によらず認められる。 一方、海底上+2 mでは、エアレーション の有無により異なった様子を示し、エア レーション時にはトレミー中心へ向かう 流れが大きくなる傾向がある。

（2）二重式トレミ一管近傍における SS

図-4 は、 $\mathrm{x}=6 \mathrm{~m}$ における表層・中層お よび底層の SS の時間変化を示したもの である。底層付近の-23.4、-22.4 mでの SS は、1 隻あたりの土砂投入が終了するま で、投入後急激に増大し直ちに低下する といった変動を繰り返していることがわ かる。このように海底近傍では投入直後 に高い SS 值を示すが、上方へ向かうに したがって低減し、-21.4、-20.4m では間 欠的に SS 值が変動している。また、海 面下-2、-10 mにおいては、SS 負荷はほと んどない。 


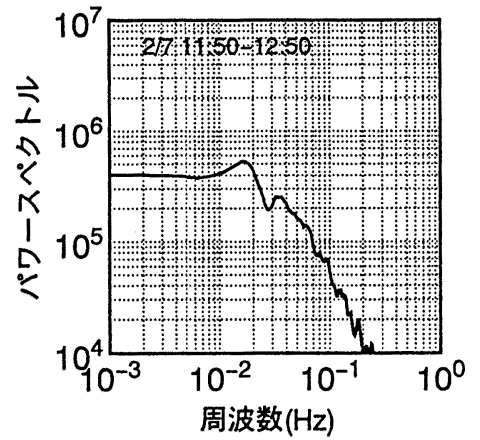

図-5 底層 SS のパワースペクトル
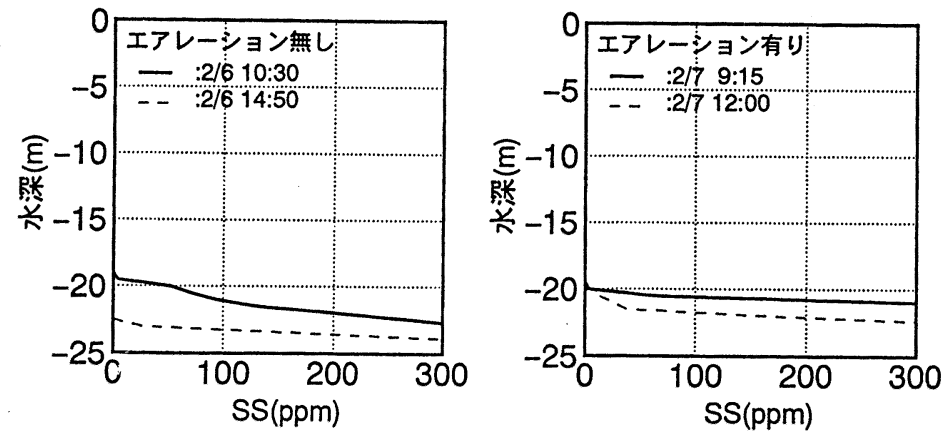

図-5 は、-23.4 m地点における 11:50 以降の 1 時間のデータから、パワースペクトルを計算したものである。 これより、エネルギーピークが周波数 0.17 (周期約 1 分）前後に見られ、土砂の投入間隔とほぼ一致しているこ とがわかる。このように、トレミー近傍底層のSS は、土砂投入時に内管内を落下した土砂が海底に衝突した後、 水平方向に移流する際に極大となる。また、海底より $3 \sim 4 \mathrm{~m}$ 上方の SS は、こうした水平方向の強い流れに伴 う連行による混合や衝突時の巻き上がりなどによるものと推定される。なお、図-5 はエアレーション時のデー タを示しているが、エアレーションがない場合でも同様の傾向となっている。

（3）二重管トレミー周辺における SS

図-6 は、 $\mathrm{x}=23 \mathrm{~m}$ における土砂投入中の SS の鉛直分布を示したものである。300ppm 以上の高い SS 值は、底 層上数 $\mathrm{m}$ 程度の薄い層厚で移動してきていることがわかる。また、分布形状は潮位によらずほとんど一定であり、 この地点への SS の移動の要因としては、潮流などによる移流拡散よりは土砂投入に伴う水平流が卓越している ものと推測される。

\section{4-3. 二重式トレミー管内の現象}

次に二重式トレミー管内の循環と SS について検討する。

\section{（1）外管内での鉛直流速}

図-7（a）、(b) の太線は、海面下 $13 \mathrm{~m}$ での鉛直流速波形（上向きが十）を示し たものである。エアレーションの有無に よらず大きな変動が生じていることがわ かる。この理由としては、流速計が固定 できなかっために、センサーの回転、振 動などの影響や台船の動摇などの影響が 生じているためと考えられる。

図-8 は、概略の流速特性を調べるため

に、それぞれのパワースペクトルを計算したものである。両者ともに、周 期 $7 \sim 8$ 秒程度のところにエネルギーのピークがあり、土砂投入時の台船 の動摇や固有周期の影響と考えられる。一方、エアレーションの有無によ る相違は、低周波数側のスペクトル形状に顕著に見られ、エアレーション 時には周波数 $0.05 \mathrm{~Hz}$ 以下のエネルギーが非常に大きいことがわかる。

そこで、カットオフ周波数 $20 \mathrm{~Hz}$ で数值ローパスフィルターをかけて取 得した時系列が図-7 中の細線である。エアの供給状態が定常状態に設定で きていないため、エア供給量と流速との定量的な関係を得るには至ってい ないが、エアレーション時には概ね $30 \sim 40 \mathrm{~cm} / \mathrm{s}$ 程度の上昇流が観測され ている。これに対し、エアレーションが無い場合には、平均流速はほぼぜ ロとなっている。

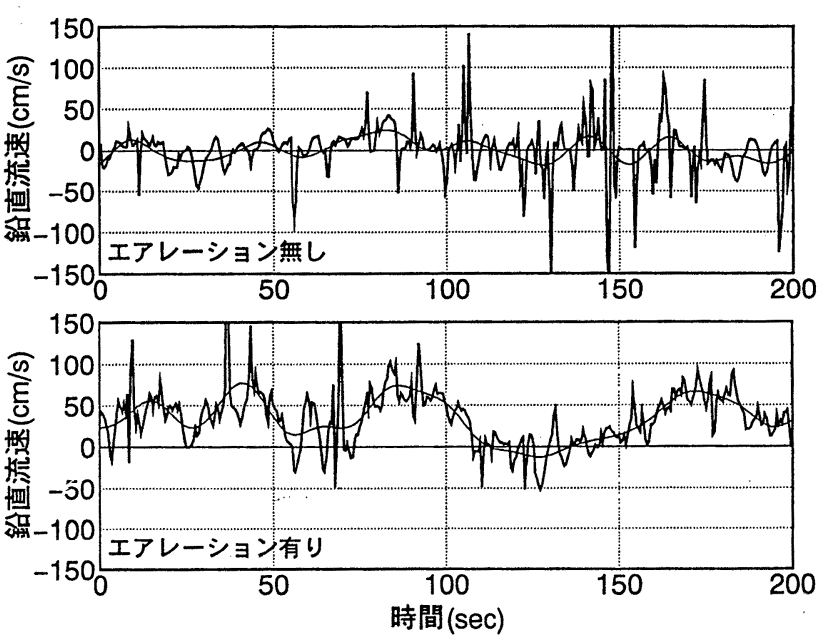

図-7 外管内の鉛直流速変動

以上より、エアレーションが無い場合、トレミー管下部および上部において外管、内管閒での水の動きはある ものの鉛直上昇流は見られず、自然循環は生じていないことがわかる。また、エアレーションによる強制循環に 
より上昇流が誘起されることが確認された。

(2) 二重式トレミー管内の SS 分布

次に、エアレーション時に生じる上昇流が二重式トレミ一管内での SS の 滞留に寄与するかどうかについて検討する。図-9 は、土砂投入後の外管内各 深度における SS を示したもので、明らかにエアレーション時に増大してい ることがわかる。また、図-10 は土砂投入終了後のトレミー内管内の SS の鉛 直分布を示したものであり、SS は海面から $20 \mathrm{~m}$ 付近（トレミー先端水深 21 m）までほぼ一様で、外管内と同様エアレーション時に SS が増大している。 なお、 $20 \mathrm{~m}$ 以媣の底層部でみられる急激な SS の低下は、エアレーション時 に緩やかとなっている。これは、鉛直上昇流により底層部の SS が滞留し、 土砂投入の合間の底層流による移流が小さくなっているためと考えられる。

このように、エアレーションによる強制循環により、1 隻あたりの土砂投 入終了後には二重式トレミ一管内の SS が増加していることが確認された。

\section{5. 二重管式トレミーの污濁低減機構}

4. の調查結果から、二重式トレミー管の効果と污濁低減機構について整理 すると以下のようになる。

(1) 污濁範囲

二重管式トレミーを用いた土砂投入では、周辺への SS 負荷が生じる領域 を底層に限定することができる。この時の底層周辺での水平的な移流拡散現 象としては、(1)土砂投入直後の急激な移流拡散、(2)投入合間に見られる緩や かな移流拡散に分類される。

(2) 土砂投入時の流況

投入直後、海底直上を側方へ移動する土砂塊の流速はかなり大きな值とな り、周辺へのSS 負荷の主因となっているものと考えられる。強制循環では、

こうした SS フラックスを低減することは難しい。しかしながら、こうした 強い側方への流れと相対し、エアレーションによる強制循環時には、その直 上でトレミ一管の中心へ向かう流れが生じる傾向が女る。

（3）循環による污濁貯留

二重式トレミー管内をエアレーションにより強制循環させることにより、

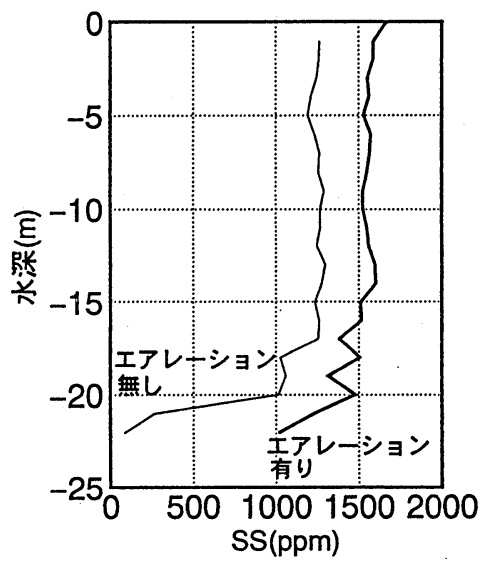

図-9 土砂投入後の外管内 SS の鉛直分布

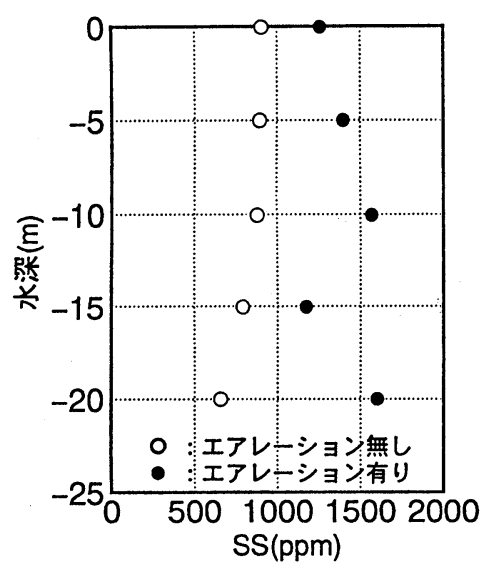

図-10 土砂投入後の内管内 $\mathrm{SS}$ の鉛直分布 SS の貯留効果を強化することができる。強制循環により吸い上げられる SS は、土砂の投入合間にトレミー下端 部に存在するもの、投入時に周辺からトレミーへ向かう流れによって集積するものであると推測される。

\section{6. おわりに}

二重管式トレミーを用いた土砂投入時の調査結果を示すとともに、二重管式トレミーの污濁低滅機構について 考察した。今回の施工条件では自然循環によるSS の滞留は認められなかったものの、エアレーションを使用し た強制循環により、SS が滞留し周囲への負荷が低減されていることが確認された。今後は、単式トレミー管と の各現象の相違やトレミー下端での循環流による吸い込み状況などを確認する必要がある。また、SS 負荷の主 要因となる投入直後における底層水平方向の移流を低減する方策や自然循環が期待できるような投入方法の検討 も必要と考えられる。

\section{参考文献}

佐藤敦久編（1987）：水環境工学、浮遊物質から見た環境保全、技報堂出版、p.247.

小川元・竹内益雄（1969）：土捨船による投棄土砂の分散、土木学会論文集、第 161 号、pp.39-49. 